\title{
Construction of Polyarylated Fluorenones via chemoselective Ru- and Pd-Catalyzed Suzuki Cross-Coupling Reactions
}

\author{
da Silva, A. J. M.;*1 Schneider, C.; ${ }^{2}$ Snieckus, V. ${ }^{2}$
}

${ }^{1}$ Núcleo de Pesquisa de Produtos Naturais, Centro de Ciências da Saúde, Bl. H, Cidade Universitária, Universidade Federal do Rio de Janeiro, Rio de Janeiro, RJ, Brazil. ${ }^{2}$ Departament of Chemistry, Queen's University, Kingston, Ontario, Canada

\section{*e-mail: alcides@nppn.ufrj.br}

Keywords: fluorenones, ruthenium, Suzuki-Miyaura

\section{INTRODUCTION}

The importance of fluoren-9-one (1), found in many biologically active products, ${ }^{1,2}$ has been emphasized in organic chemistry. It consists of essential structural backbone of various pharmaceuticals. Also number of natural products have been found containing fluoren-9-ones showing a range of biological acitivities; e.g. dengibsin, dengobsinin, dendroflorin and kinobscurinone. Utility of fluorenone derivatives as photosensitizers in organic photoconductor devices and their electrical and optical properties are also important. ${ }^{3}$<smiles>O=C1c2ccccc2-c2ccccc21</smiles>

1

Figure 1. Fluorenone System

\section{RESULTS AND DISCUSSION}

We have discovered $\mathrm{C}-\mathrm{O}$ arylation reactions of fluorenones (2) and (3) under Ru-catalyzed ChataniKakuichi coupling, ${ }^{4}$ which in combination with $\mathrm{Pd}$ Suzuki cross-coupling lead to respectively mono(4), 1,4-di- (6 1,8-di- (5) and 1,4,8-tri-substituted fluorenones (7) of structural interest (Scheme1). The fluorenone starting materials were prepared by directed ortho and remote metalation-Suzuki coupling strategies. Under these conditions it was possible to get regioselective $\mathrm{C}-\mathrm{O}$ activation to afford 1-aryl substituted fluorenones (4) in moderate to excellent yields. The 1,4 -diaryl -substituted fluorenones (6) were prepared in good yields by combination between Suzuki cross coupling and Rucatalized sequence of reactions. When 1,8dimethoxy-fluorenone (2) was treated with excess amount of $\mathrm{Ar}^{1} \mathrm{~B}$ (neop) in toluene (MW / $150{ }^{\circ} \mathrm{C}$ ), it was possible to obtain the 1,8-diaryl- substituted fluorenones (5) in moderate yields. The synthesis of (7) is in progress.

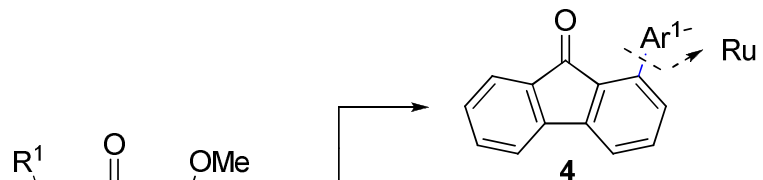<smiles>C=C1c2c(C)cccc2-c2cccc(C)c21</smiles>
$\mathrm{R}^{1}=\mathrm{H}$, OMe, OTf 2

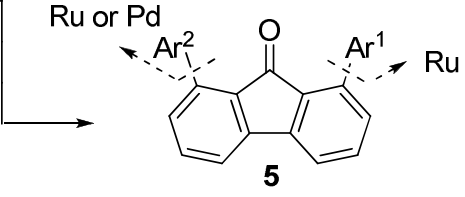<smiles>[R]C(CC)CC(=O)CCOC</smiles><smiles>[R]c1cccc2c1C(=C)c1c(OC)c(C)cc([R])c1-2</smiles>

$\mathrm{R}^{1}=\mathrm{H}$, OMe, OTf $\mathrm{R}^{2}=\mathrm{H}, \mathrm{Cl}$

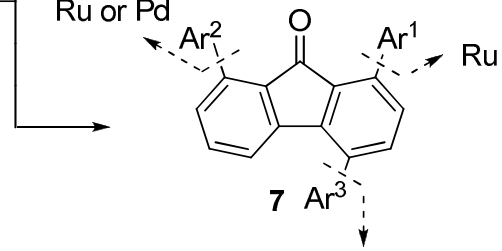

$\mathrm{Pd}$

Scheme 1

\section{CONCLUSION}

We developed an efficient approach to prepare mono and di-aryl substituted fluorenones by combination of Suzuki reactions and Ru-catalyzed $\mathrm{C}-\mathrm{O}$ activation. The syntheses of poly-aryl substituted fluorenones are in progress.

\section{ACKNOWLEDGEMENTS}

CAPES, UFRJ, Queen's University

\section{REFERENCES}

${ }^{1}$ Perry, P. J.; Read, M. A.; Davies, R. T.; Gowan, S. M.;Reszka, A. P.;

Wood, A. A.; Kelland, L. R.; Neidle, S. J. Med. Chem. 1999, 42, 2679.

${ }^{2}$ Hartung, C. G.; Snieckus, V. Modern Arene Chemistry; Astruc, D., Ed.; Wiley-VCH: New York, 2002;330. ${ }^{3-T i l l y, ~ D . ; ~ S a m a n t a, ~ S . ~ S . ; ~ F a i g l, ~ F . ; ~}$

Mortier, J. Tetrahedron Lett. 2002, 43, 8347. ${ }^{4-}$ Kakiuchi,F; Usui, M.; Ueno,

S.; Naoto Chatani, N.; Murai, S., J. Am. Chem. Soc. 2002, 126, 2706. 